\title{
NAKIT I UMJETNOST PEĆINe Vlakno
}

\author{
DARIo VujeVić \\ Sveučilište u Zadru \\ Odjel za arheologiju \\ Obala kralja Petra Krešimira IV.,2 \\ HR-23000 Zadar \\ dario.vujevic@gmail.com
}

\author{
Mate Parica \\ Sveučilište u Zadru \\ Odjel za arheologiju \\ Obala kralja Petra Krešimira IV.,2 \\ HR-23000 Zadar \\ mateparica@gmail.com
}

\author{
UDK: 903.25(497.5 Savar)"632" \\ Stručni rad \\ Professional paper \\ Primljeno / Received: 2010-06-11
}

U članku se obrađuju nakitni predmeti pronađeni na lokalitetu Vlakno na Dugom otoku, pećine koja sadrži slojeve gornjeg paleolitika i mezolitika. Autori analiziraju geostrateški položaj pećine u vrijeme epigravetijena, te opisuju promjene u okolišu uvjetovane znatno nižom razinom mora. Nakit od probušenih zuba jelena, morskih puževa i školjaka, a posebice gomolje s urezanim prikazima, uspoređuju sa sličnim nalazima obiju jadranskih obala. Ističu važnost pećine Vlakno za ukupno poznavanje nakita i umjetnosti gornjeg paleolitika.

KLJUČNE RIJEČI: Dugi otok, pećina Vlakno, paleolitik, epigravetijen, rožnjak s urezima, nakit

Paleolitik na Dugom otoku do nedavno je isključivo bio poznat po nalazištima na otvorenom vezanim uz ležišta sirovina, ${ }^{1}$ dok su naselja u pećinama ostala potpuno nepoznata, iako na otoku postoji 57 različitih speleoloških objekata, a utvrđeno je postojanje većeg broja objekata koji su potopljeni ili su u razini mora na području otoka. ${ }^{2}$ Međutim, osim Vlakna, niti jedan drugi objekt do sada nije bio predmet arheoloških istraživanja.

Pećina Vlakno, čije je istraživanje započeo 2004. godine Zdenko Brusić3 ${ }^{3}$ nalazi se na središnjem dijelu Dugog otoka između mjesta Luke i Savra, stotinjak metara od obale s njegove sjeveroistočne strane, na visini od 30 metara iznad mora. Ima široki otvor, okrenut na jug/jugozapad koji je pregrađen recentnom izgradnjom debelog suhozida s ostavljenim prolazom. Predpećinski prostor također je ograđen suhozidom koji mu daje kvadratni oblik. Pećina ima suho, ravno dno s finom sipkom zemljom. ${ }^{4}$

Izgledom, veličinom i orijentacijom pećina je bila pogodna za korištenje manjoj skupini tijekom cijele godine. U vrijeme kada nastaju slojevi iskopavani u najnovijoj kampanji arheoloških istraživanja, dakle prije 15/14.000 godina, razina mora je bila najmanje $65 \mathrm{~m}$ niža od današnje, a područje srednjeg Jadrana bilo je svedeno na 1/7 današnje površine (Karta 1). ${ }^{5}$ Pećina se tada nalazila visoko iznad mora, a cijeli otok je imao oblik grebena visokog od 100 do $400 \mathrm{~m}$ iznad tadašnjih dolina i bio je povezan s današnjim kopnom. ${ }^{6} \mathrm{U}$ to vrijeme širi zadarski i sjeverni jadranski prostor pokazuje znatne ambijentalne razlike u odnosu na današnje vrijeme. Prostrano područje današnjega sjevernog Jadrana je za vrijeme nižih morskih razina bila dolina rijeke

\footnotetext{
${ }^{1}$ M. MALEZ, 1979; ك̌. BATOVIĆ, 1988.

${ }^{2}$ K. DŽAJA, 2003, 29.

${ }^{3}$ Zahvaljujemo se prof. Z. Brusiću na svim informacijama i ustupljenom materijalu iz prve dvije kampanje za objavu.

${ }^{5}$ M. SURIĆ, 2006, 177. Izračun morske razine dobiven je na osnovu krivulje relativne morske razine. Vidi: M. SURIĆ, 2006, 168, sl. 104 6 Š. BATOVIĆ, $1988,7$.
} ${ }^{4}$ Z. BRUSIĆ, 2005, 197-198. 


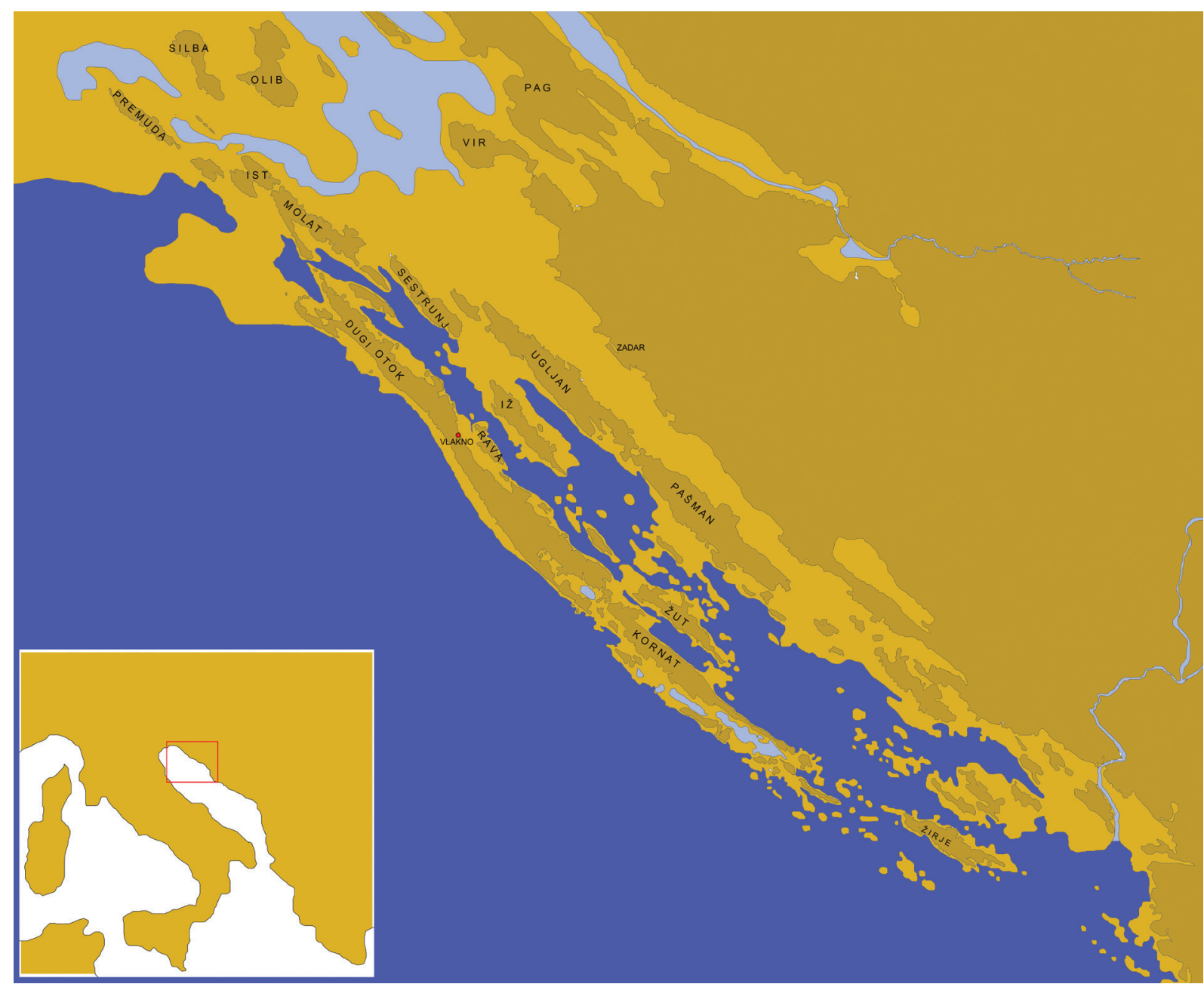

Karta 1. Zadarsko otočje u vrijeme kada je morska razina niža za 65 metara.

Map 1. Zadar archipelago in the period when sea level was $65 \mathrm{~m}$ lower than today.

Po i njezinih brojnih pritoka s Apeninskog poluotoka, Alpa i Dinarida. ${ }^{7}$ Dugi otok zajedno s kornatskim otočjem, te manjim otocima kao što su Žut, Rava, Zverinac, čini veću cjelinu koja je preko otoka Molata i Ista spojena s tadašnjim kopnom. Ugljan, Pašman, Iž, te okolni prostor, također je dio jedinstvenoga kopnenog područja. Dubinske depresije Virskog mora, prostora oko otoka Paga, te područja između Silbe i Premude, izolirane su od otvorenog mora, i najvjerojatnije su bile ispunjene slatkom vodom iz rijeke Zrmanje i bogatih podvelebitskih izvora.

Sjevernojadranska dolina, koja je u ovome razdoblju kopno, prostor je koji pruža pogodne životne uvjete životinjskim stadima sa sjevera. ${ }^{8}$ Tako složeni okoliš, s razvedenim oblikom obale, mnoštvom morskih i slatkovodnih rukavaca, tokova i ostalih barijera, idealan je za vrlo uspješan lov krupnih životinja koje su na okolnom području obitavale ili su bile u stalnoj selidbi sa sjevera na jug kontinenta ili obrnuto. 

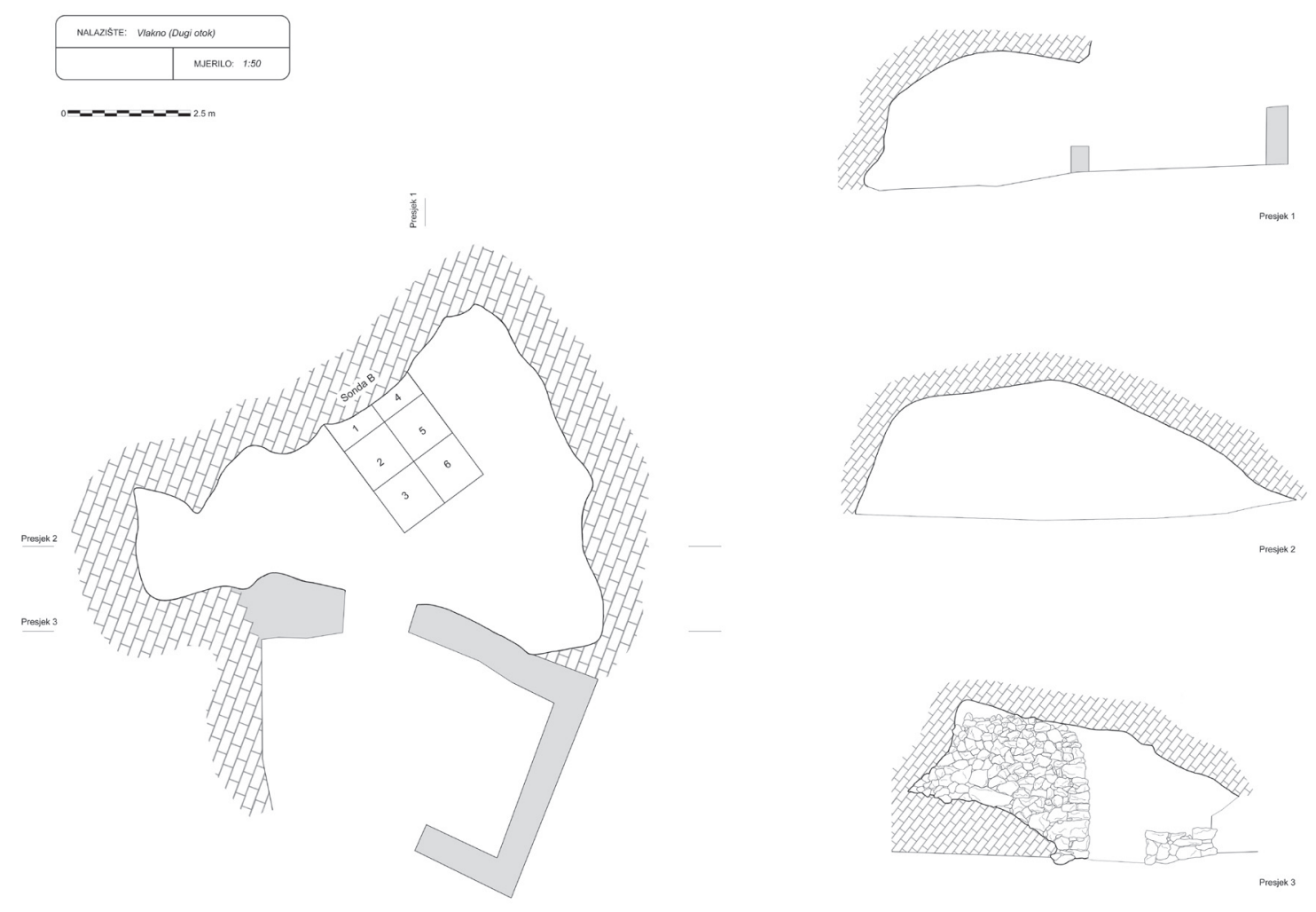

Sl. 1. Tlocrt i presjeci pećine.

Fig. 1. Layout and cross-section views of the cave.

Još je jedna pojava mogla utjecati na odabir pećine. Na današnjoj površini otoka nema značajnijih stalnih izvora, Jedine značajnije pojave slatke vode na površini u Žmanskim su jezerima, no tu se ponajprije radi o atmosferskoj vodi koja se zadržava u ovim depresijama zahvaljujući hidrostatskom tlaku. ${ }^{9}$ Pa ipak toponim Šipnatica, koji se i danas koristi za uvalu ispod pećine, najčešće je vezan uz vodu, te može ukazivati na postojanje podvodnog izvora pitke vode. Taj izvor bi, u vrijeme niske razine mora, dakle u vrijeme nastanka slojeva u pećini, predstavljao važnu odrednicu u odabiru staništa na području siromašnom vodom, to više što mnogi arheološki podatci govore da je za paleolitičke skupine pri odabiru mjesta blizina vode prioritetnija od blizine sirovine. ${ }^{10}$

Nakon tri godine stanke, početkom 2010. godine provedena je treća kampanja arheoloških istraživanja. Cilj je i dalje ostao isti, a to je utvrđivanje kompletne stratigrafije nalazišta, pa se iskopavanje vršilo unutar prethodno otvorene Sonde B (Slika 1). Trenutno je moguće pratiti kontinuitet epipaleolitika i mezolitika. Pri iskopavanju 2007. godine iskopano je otprilike do $200 \mathrm{~cm}$ dubine, a na dnu se pojavio sloj tefre. Riječ je o $5 \mathrm{~cm}$ debelom sloju žutog napuljskog 


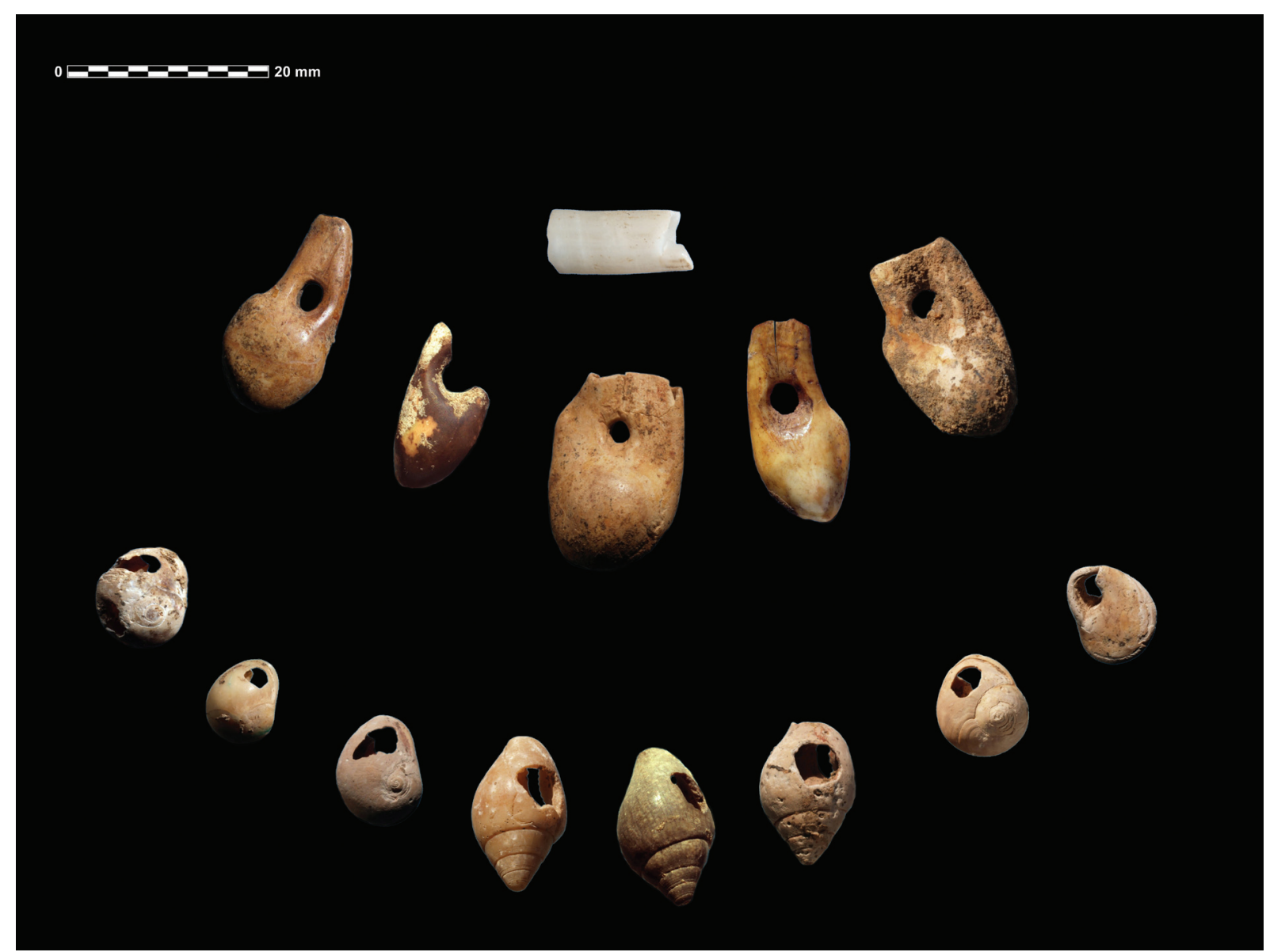

Sl. 2. Nakit od životinjskih zuba i morskih puževa (foto: M. Parica).

Fig. 2. Jewelry made of animal teeth and sea snails (photo: M. Parica).

tufa izbačenog pri erupciji na Flagrejskim poljima u blizini Napulja. Analize pokazuju da je ovaj sloj nastao prije 14.500 godina. ${ }^{11}$ Gotovo identične naslage postoje i u Veloj spili, gdje datumi sloj tefre stavljaju u vrlo širok raspon od 13.500 do 11.900 kal. godina prije Krista. ${ }^{12}$

U novoj kampanji iskopano je dodatnih $80 \mathrm{~cm}$ naslaga ispod tefre, a niti do kraja kampanje nije dosegnuto dno pećine. ${ }^{13}$ Već na početku novog iskopa moglo se primijetiti opadanje ostataka morskih organizama, a ostatci kopnenih životinja najviše se odnose na velike preživače. Iako su i dalje prisutne u velikom broju, manja je koncentracija kremenih alatki. Javljaju se koštani alati, kao i probušeni zubi jelena (Cervus elaphus) i probušene školjke i puževi (Cyclope neritea i Columbella rustica).${ }^{14}$ Uspoređujući s Velom spilom, možemo primijetiti sličan razvoj, gdje je prelazak u starije razdoblje također obilježen promjenama u svim vrstama nalaza, uključujući i one koje ukazuju na društvene aspekte života. ${ }^{15}$

${ }^{11}$ Z. BRUSIĆ, 2008, 402.

${ }^{12}$ D. RADIĆ et al., 2008, 17.

${ }^{13}$ Kako je obrada materijala iz slojeva u tijeku, a isti nisu direktno vezani za temu članka, za sada donosimo samo sumarne rezultate istraživanja, dok će potpuni izvještaj biti naknadno objavljen.

${ }^{14}$ Z. BRUSIĆ, 2008, 401-402.

${ }^{15}$ B. ČEČUK, D. RADIĆ, 2005; D. RADIĆ et al., 2008. 
Ispod sloja tefre mogu se izdvojiti tri glavna sloja odvojena dvama tankim proslojima pepela i zagorjele zemlje, koji zapravo predstavljaju hodne površine iz vremena kada je pećina bila korištena. Preliminarne analize materijala iz sva tri sloja i dalje ukazuju na razdoblje epigravetijena, što se poklapa s općim razvojem gornjeg paleolitika na obje strane Jadrana. U Hrvatskoj je poznato tek nekoliko nalazišta iz tog vremena. Najpoznatija je Šandalja II gdje je, na osnovi analiza Karavanić dokazao postojanje dvije vremenski različite faze epigravetijena istočnog Jadrana, koje se razaznaju prema tipološkim i tehnološkim karakteristikama. ${ }^{16}$ Treba spomenuti i debele naslage bogate materijalom iz Vele spile na otoku Korčuli, koja se i najbolje može usporediti s Vlaknom. ${ }^{17}$ Pupićina peć odgovara drugom stupnju epigravetijena, a Vešanska peć sadrži industriju epigravetijena datiranu u vrijeme između 13.400 i 11.230 kal. godina prije Krista. ${ }^{18}$ Slična je situacija i s Nugljanskom peći. ${ }^{19}$ Nalaze epigravetijena dala je i špilja Kopačina na SZ strani otoka Brača, a datumi datiraju slojeve u razdoblje između 13.000 i 11.888 godina prije sadašnjosti. ${ }^{20}$

Najbogatiji nalazima bio je sloj direktno ispod tefre. Već u prošloj kampanji, kada se djelomično zakopalo i u ovaj sloj, u njemu su pronađeni probušeni koštani zubi jelena i probušeni puževi, te nešto koštanog alata. Nova kampanja donijela je još tri probušena zuba jelena, tri školjke s rupom na zatku (rod Glycimeris) i fragmente deset koštanih šila i probojaca. Sveukupno, u dvije posljednje kampanje pronađeno je osam probušenih zuba jelena, šest probušenih morskih puževa, šest različitih probušenih školjki, te perlica od školjke roda Entalina (Dentalium tetragonum) (Slika 2) .

Izrada nakita iz Vlakna vrlo je jednostavna. Bez posebne pripreme, na najtanjem dijelu zuba ili školjke, oštrim predmetom izdubljuje se rupa ovalnog oblika (Slike 3, 4). S obzirom na nepravilne oblike rupa, za bušenje nije upotrjebljeno svrdlo nego je riječ o nekom oštrijem predmetu. Urezi uz rupu na jednom zubu to dodatno potvrđuju (Slika 3)

Pojava nakita u epigravetijenskim slojevima Vlakna ne odstupa od općih karakteristika vremena, ali se brojkom izdvaja od ostalih nalazišta na istočnoj obali Jadrana. Primjera radi u razdoblju gornjeg paleolititika na području Istre, nakit je zabilježen samo na četiri nalazišta, u Šandalji II, Romualdovoj pećini, Pupićinoj peći i u Vešanskoj peći. Najzastupljeniji su životinjski zubi, no na sva četiri nalazišta pronađeno je ukupno 9 komada. Od materijala porijeklom iz mora izrađivani su uglavnom privjesci i to, po jedna školjka iz Šandalje II i Pupićine peći, te jedan bušeni morski puž (vrste Columbella rustica) iz Pupićine peći. ${ }^{21}$

Nakit možemo definirati kao izrađevinu koja nema nikakvu praktičnu funkciju osim ukrašavanja tijela. Ono je svojevrsni oblik neverbalne komunikacije svojstveno socijalnim skupinama i ljudskim grupama u određenom vremenu na određenom prostoru. ${ }^{22} \mathrm{U}$ tradicionalnim društvima perlice često označavaju pripadnost pojedinca jednoj ili više socijalnih grupa. Odnosi mogu biti različiti: rodovska povezanost, bogatstvo, dob, spol, biološko stanje, a također mogu ukazivati na status ili položaj unutar zajednice. ${ }^{23}$ Nije isključeno niti da je korištenje ove vrste nakita izraz poštovanja prema životinjama, izdizanje životinje iznad puke lovine. ${ }^{24}$ Iako je skupina koja je mogla nastanjivati pećinu Vlakno bila relativno mala, i unatoč činjenici da su svi predmeti pronađeni u istom sloju na manjoj površini, nemamo nikakvih dokaza da probušeni primjerci pripadaju istom nakitu kojeg je nosio

\footnotetext{
${ }^{16}$ I. KARAVANIĆ, 1999.

${ }^{17}$ B. ČEČUK, D. RADIĆ, 2005; D. RADIĆ et al., 2008.

${ }^{18}$ D. KOMŠO, P. PELLEGATI, 2007, 30-35.

${ }^{19}$ I. KARAVANIĆ, 1999, 102.

${ }^{20}$ I. KARAVANIĆ, 1999, 103-104.
}

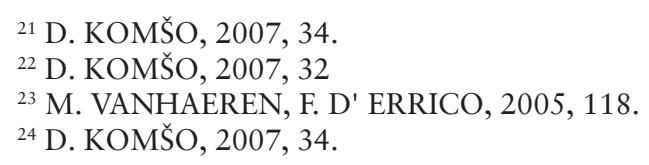




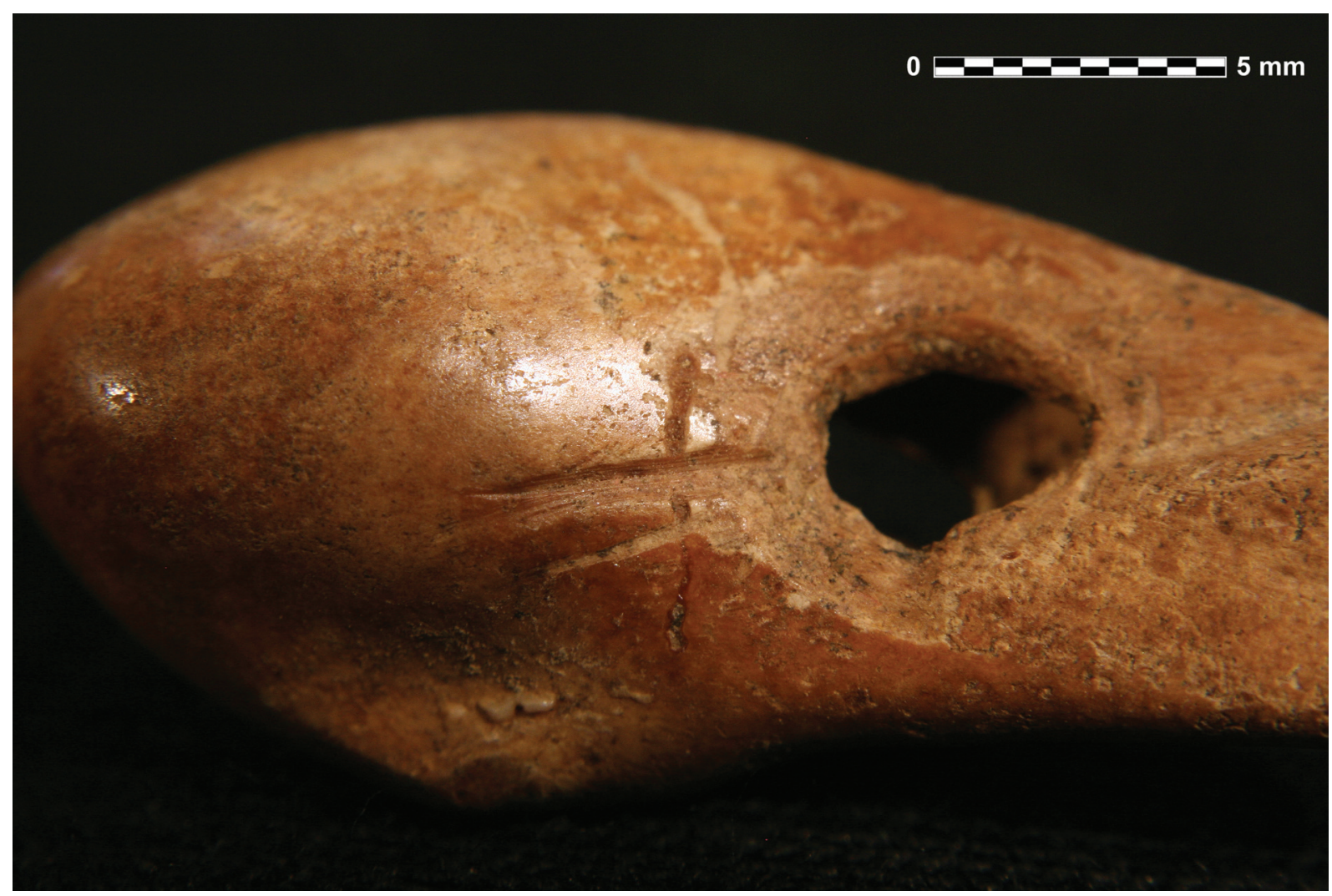

Sl. 3. Detalj probušenog zuba s tragovima alata (foto: M. Parica).

Fig. 3. A detail of a perforated tooth with tool traces (photo: M. Parica).

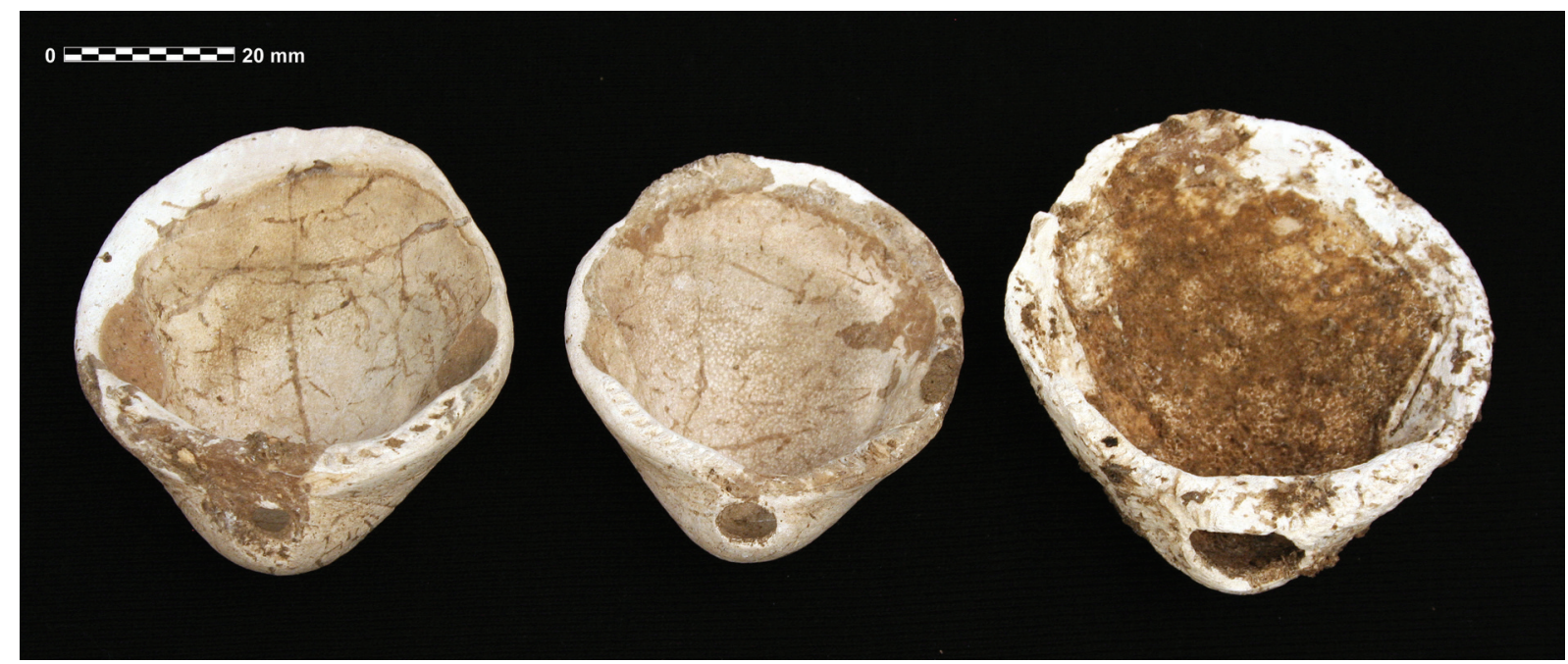

Sl. 4. Školjke s rupom na zatku (foto: M. Parica).

Fig. 4. Shells with a hole at the back (photo: M. Parica). 
samo jedan pojedinac. Time ne možemo govoriti o nakitu kao odrednici statusa unutar zajednice, ali čak i sama želja za ukrašavanjem može odavati smisao za estetiku zajednice.

Pojam estetike dobiva još više na značaju pronalaskom dva fragmenta gomolja rožnjaka u istom sloju. Jedan od njih ukrašen je nizom kratkih, paralelnih i dva vodoravna ureza na okorini (Slika 5). Nema sumnje da su umjetno izrađeni. Vodoravni urezi na predmetu idu od jednog do drugog kraja sačuvanog dijela, dok okomiti počinju na gornjoj vodoravnoj liniji, prelaze preko druge i idu do ruba kamena. Riječ je o dijelu većeg prikaza, koji se nastavlja u tri smjera u odnosu na sačuvani prikaz, ali nažalost nemamo ostale fragmente da bi mogli govoriti o vrsti prikaza. Nodul je slomljen, sačuvan nam je samo dio trokutastog presjeka duljine 3,6 cm. Preliminarne analize pokazuju da je prije loma bio izložen zagrijavanju, ali teško je reći da li je to iz razloga da mu okorina omekša, čime bi urezivanje prikaza bilo uvelike olakšano, ili je predmet naknadno bio izložen vatri, što je moglo utjecati i na njegov lom. ${ }^{25}$

U istom sloju pronađen je i drugi fragment nodula, polukružnog presjeka, dužine 2,3 cm (Slika 6). Urezi na okorini su plitki, ali za razliku od prethodnog fragmenta, ispunjavaju cijelu površinu. Riječ je o nizu kosih paralelnih kratkih ureza koji idu uokolo odbojka. Datumi dobiveni za ovaj sloj pokazuju vrijeme od 12.710 do 12.120 kal. godina prije Krista (14.660 do 14.060 kal. godina prije sadašnjosti). ${ }^{26}$

Prikazi ili apstrakcije su općenito prihvaćeni kao arheološki izraz suvremenih kognitivnih sposobnosti. Često su zabilježeni na nalazištima gornjeg paleolitika. ${ }^{27}$ No kakva nam objašnjenja nude predmeti iz Vlakna i kako im pristupiti? Korištenje pojma umjetnosti je problematično jer pretpostavlja estetiku i svrstava prikaze u naše kulturne kategorije. ${ }^{28} \mathrm{~Pa}$ ipak umjetnost je tehnički izraz koji je u upotrebi toliko dugo da ga je teško zamijeniti. Iz tog razloga u nekom širokom shvaćanju prikazi iz Vlakna mogu spadati u kategoriju umjetnosti. Ako želimo izbjeći naglašavanje samo estetskog fenomena, možda bi bolji termini bili gravure, urezi ili u najširem objašnjenju crtež. Jer prikazi bi mogli biti znakovi ili sredstva informacija. Pojam crteža, shvaćan u smislu prikaza oblika, predmeta ili pojava na nekoj površini ili pak gravura kojom se više naglašava i tehnička strana možda bi najbolje odgovarali prikazima iz Vlakna.

Značenje ovih predmeta nam pak, do mogućeg pronalaska još kojeg fragmenta, ostaje potpuno nepoznato. Nema naznaka funkcionalnih svojstava ureza, pa je realno pretpostaviti da je njihova namjena u najmanju ruku estetske naravi. Postoji mogućnost i da prikazi na nodulima iz Vlakna imaju mnogo složenije tumačenje. Arheolozi već odavno pretpostavljaju da dio "umjetnosti gornjeg paleolitika" služi za pohranu informacija. Geometrijske forme mogu predstavljati različite znakove ili simbole. Predmeti pri tom služe kao produžetak biološke memorije, sredstvo za spremanje informacija u svijetu koji ne poznaje pismo. ${ }^{29}$ Tumačenja ovih simbola idu od znakova predalfabetskih sistema do sustava notacija i oznaka različitih vrsta, ili čak neke vrste igara. Pojedina objašnjenja idu čak do razine entopijskih fenomena tj. slika koje su vidljive tijekom transa ili halucinacija. ${ }^{30}$ Današnjem čovjeku značenje znakova je zaštićeno i teško ga je interpretirati. Apstraktni motivi mogu biti dvosmisleni ili mogu biti višeznačni u isto vrijeme. Osim toga oni mogu različitim ljudima predstavljati različite pojmove ili informacije. ${ }^{31} \mathrm{~K}$ tome kompliciraniji motiv ne

25 Zahvaljujemo Z. Perhoču na preliminarnoj analizi nalaza.

${ }^{26}$ Beta Analytic, Beta-277309, 12350 70 BP (2 Sigma kalibracija: Cal BC 12710 to 12120 / Cal BP 14660 to 14060). Calibration Database IntCal04, Calibration Issue of Radiocarbon (Volume 46 , nr 3 , 2004).

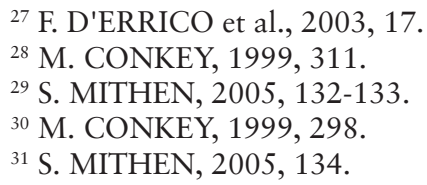




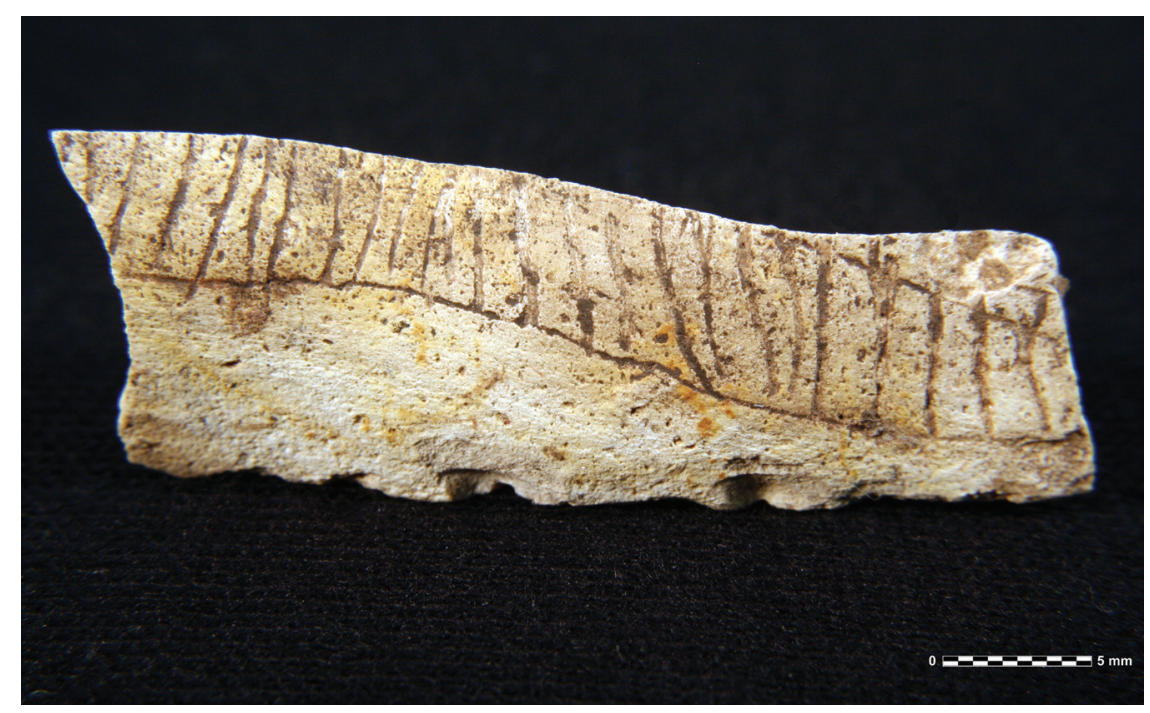

Sl. 5. Rožnjački gomolj s urezima (foto: M. Parica).

Fig. 5. Chert nodule with incisions (photo: M. Parica).

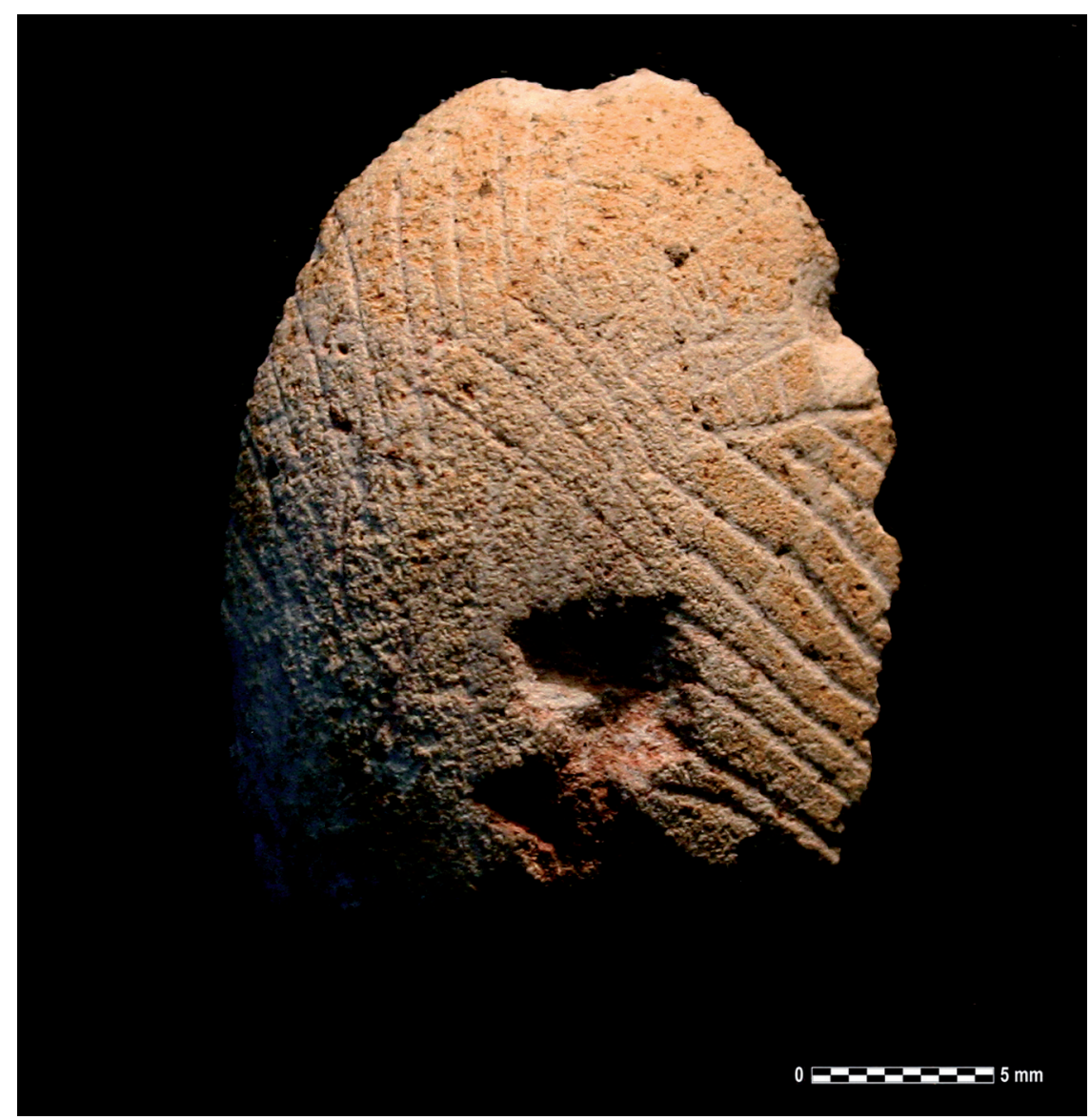

Sl. 6. Rožnjački gomolj s urezima (foto: M. Parica).

Fig. 6. Chert nodule with incisions (photo: M. Parica). 
mora nužno imati kompliciranije značenje od jednostavnog motiva. ${ }^{32} \mathrm{U}$ određenom trenutku ovi znakovi mogu određenoj osobi u određeno vrijeme prenijeti određenu poruku. Nama je možda teško shvatiti poruku s današnjeg stajališta, ali ona je bila razumljiva ljudima u ono vrijeme.

Nisu to jedini ukrašeni predmeti iz Vlakna. Na jednom koštanom šilu nalazi se niz vodoravnih, kratkih ureza na proksimalnom dijelu, koji nisu produkt obrade ili korištenja kosti (cutmarks), nego nedvojbeno predstavljaju ukras samog predmeta. Slični urezi (četiri kratka ureza) nalaze se i na distalnom dijelu koštanog probojca. Kao i kod prethodnog nalaza i ovi urezi mogu imati samo estetsko značenje. No mogu označavati vlasništvo ili pripadnost grupi, ili, pošto se urezi ponavljaju mogu predstavljati sistem brojeva. ${ }^{33}$

U Hrvatskoj postoji samo jedan predmet sličan gomoljima iz Vlakna. Riječ je o kamenu s urezima iz Šandalje II, iz sloja B/s koji se datira u kasni epigravetijen, sa sačuvanim mrežastim motivom. ${ }^{34}$ Usporedbu možemo povući i s različitim koštanim pločicama s istog nalazišta, koje sadrže različite urezane, većinom mrežaste motive, slične onima s kamena iz Vlakna. Među njima posebno se ističe pločica iz ranog epigravetijena s nizom dužih paralelnih, vodoravnih ureza $\mathrm{s}$ nizom kratkih okomitih ureza na vrhu, zasigurno dio većeg prikaza. ${ }^{35}$ Iz Šandalje II potječe i najstariji predmet s namjerno izvedenim urezima. Riječ je o koštanoj alatki s urezanim paralelnim linijama pronađenoj u orinjasijenskom sloju. ${ }^{36}$

Slični predmeti postoje na okolnim prostorima. U Crnoj Gori, na lokalitetu Bioče, u slojevima koji sadrže musterijensku kulturu pronađen je manji oblutak s urezima. Petrološka analiza je potvrdila da osim prirodnih ureza i pukotina, sadržava i umjetno napravljene ureze. Među njima dominira središnja urezana linija koja ide uokolo cijelog oblutka i na mjestu spajanja se račva, što se ne bi moglo dogoditi da je prirodno puknula. Ostale linije tvore seriju ravnih ili zaobljenih plitkih ureza, koji sjecištima tvore romb, kvadrat i trokute. ${ }^{37}$

Gravirani prikaz pronađen je u Badnju je na velikom kamenom bloku koji se odlomio od stjenke pećine. Prikazuje figuru konja gledanu s desnog boka. U jačim potezima ugravirano je desno bedro konja s nogom koja je opružena, dok je lijeva dana u tankim crtama s položajem koji odgovara konju u pokretu. U uglu između trbuha i bedara povučeno je nekoliko okomitih crta. Preko bedara ucrtana je linija koja s kosim vrhom podsjeća na strelicu S obzirom na nalaze na vrhu sloja nastanak ove gravure ne može biti mlađi od 11.000 godina prije sadašnjosti, a jedva je moguće da bi mogao biti stariji od 15.000 godina prije sadašnjosti. ${ }^{38}$

Nešto je veći broj nalaza ove vrste u Italiji. U pećini Paglicci je, datiran u razdoblje 16.03015.480 godina prije sadašnjosti (nekalibrirano), pronađen oblutak s urezima na okorini koji je nakon urezivanja odbijen. ${ }^{39}$ Prikaz je teško prepoznatljiv. U Riparo Maurizio, jezgra i odbojak imaju linearne ureze na okorini, ali vjerojatno nije riječ o naturalističkom prikazu. Pronađeni su u sloju ranog epigravetijena. ${ }^{40}$ Nešto mlađe gravure na kamenim fragmentima potječu iz pećine Romanelli, koncentrirani uglavnom na dnu sloja $C$ datiranog u razdoblje između 9,790 \pm 80 i 10,390 \pm 80 godina prije sadašnjosti (nekalibrirano). ${ }^{41}$ Prikazi su različiti, a najveći broj motiva otpada na geometrijske figure. ${ }^{42}$

\footnotetext{
${ }^{32}$ R. BRADLEY, 2005, 10.

${ }^{33}$ S. MITHEN, 2005, 132-133.

${ }^{34}$ I. KARAVANIĆ, 1999, 136, T. 45, 40.

${ }^{35}$ I. KARAVANIĆ, 1999, 85, T. 54, 2.

${ }^{36}$ I. KARAVANIĆ, 1999, 84, T. 53, 10.

${ }^{37}$ Lj. ĐURIČIĆ, 2006, 190-191.
}

\author{
${ }^{38}$ Đ. BASLER, 1976, 7-8. \\ ${ }^{39}$ M. MUSSI, 2002, 266-267. \\ ${ }^{40}$ M. MUSSI, 2002, 267. \\ ${ }^{41}$ M. MUSSI, 2002, 296. \\ ${ }^{42}$ M. MUSSI, 2002, 298, Fig. 7.9.
}


Slični prikazi izvedeni na oblucima, kao jedan vid pokretne umjetnosti, ali izvedeni slikanjem, pronađeni su i u epigravetijenskim slojevima Arene Candidae i Riparo Dalmeri, a među njih mogu se uvrstiti i obluci s oslikanim paralelnim linijama pronađeni na nalazištima Grotta Continenza u središnjoj i Grotta della Madonna u južnoj Italiji. Stilističkoj usporedbi odgovara i kronološka, gdje je većina oblutaka s prikazom datirana u razdoblje od 13 do 10 tisuća godina prije sadašnjosti. ${ }^{43}$

\section{ZAKLJUČAK}

Pojava većeg broja nakitnih predmeta poput probušenih zuba, puževa i školjaka, zatim ukrasnih ureza na koštanom oruđu, te naposljetku pronalazak prikaza na okorini rožnjačkih nodula, ističu pećinu Vlakno kao jedno od najbogatijih istočnojadranskih nalazišta, tim više što je istraživana manja površina od ostalih paleolitičkih i mezolitičkih lokaliteta.

Razloge ovakvoj koncentraciji vrijednih nalaza možemo tražiti i u vrlo povoljnom geografskom položaju prostora Dugog otoka u odnosu na sjevernojadranski prostor koji obiluje stadima krupnih životinja. Čak i njihova eventualna migracijska kretanja u pravcu sjever-jug i natrag mogu se odvijati isključivo preko uskog područja današnjeg sjevernog dijela Dugog otoka, Molata i Ista, iz razloga što je zapadno morska barijera, dok su na istoku veće vodene površine i teško premostiva planina Velebit. Rezultat svega mogla bi biti iznimna uspješnost u lovu, a poznato je da ekonomska uspješnost i stabilnost povoljno utječu na razvoj umjetnosti.

Većina predmeta je čisto utilitarnog karaktera i spada u domenu estetike, možda u najširem smislu te riječi i u domenu umjetnosti. Većinom je riječ o dijelovima nakita, ali među pronađenim predmetima posebno se ističe gomolji s dijelovima urezanih prikaza. Nije isključeno da je prikaz nekoć imao i dublje, simboličko značenje, iako do pronalaska drugih fragmenata svako tumačenje ostaje na razini pretpostavke.

Najbrojnije analogije sa pronađenim predmetom nalazimo u Italiji, što nimalo ne treba čuditi budući da je sjevernojadranski prostor u to vrijeme kopno, te povezuje obje jadranske obale, tako ih svrstavajući u jedinstveni kulturni krug. Postupno podizanje morske razine potopilo je spomenuti prostor, te vjerojatno preplavilo nekolicinu kako pećinskih, tako i nalazišta na otvorenom prostoru.

\section{LITERATURA}

BASLER, Đ., 1976. - Đuro Basler, Paleolitsko prebivalište Badanj kod Stoca, Glasnik zemaliskog muzeja u Sarajevu, n.s., 29 (1974), Sarajevo, 5-18.

BATOVIĆ, Š., 1988. - Šime Batović, Paleolitički i mezolitički ostaci s Dugog otoka, Poročilo o raziskovanju paleolita, neolita in eneolita $v$ Sloveniji, XVI, Ljubljana, 7-53.

BRADLEY, R., 2005. - Richard Bradley, Rock art and the prehistory of Atlantic Europe; Signing the Land, Taylor \& Francis e-Library.

BRUSIĆ, Z., 2005. - Zdenko Brusić, R. Br. 98 - Pećina Vlakno, Hrvatski arheološki godišnjak, 1 (2004), Zagreb, 197-199.

BRUSIĆ, Z., 2008. - Zdenko Brusić, R. Br. 98 - Pećina Vlakno, Hrvatski arheološki godišnjak, 4 (2007), Zagreb, 400-403.

${ }^{43}$ M. MUSSI et al., 2008. 
CONKEY, M., 1999. - Margareth W. Conkey, A history of the interpretation of European "palaeolithic art": magic, mythogram, and metaphors for modernity, Handbook of human symbolic evolution (Lock, A., Peters, C., eds.), Oxford, 288-349.

ČEČUK, B., RADIĆ, D., 2005. - Božidar Čečuk, Dinko Radić, Vela spila, višeslojno pretpovijesno nalazište, Vela Luka.

D'ERRICO, F. et al., 2003. - Francesco d'Errico, Christopher Henshilwood, Graeme Lawson, Marian Vanhaeren, Anne-Marie Tillier, Marie Soressi, Frederique Bresson, Bruno Maureille, April Nowell, Joseba Lakarra, Lucinda Backwell, Michele Julien, Archaeological Evidence for the Emergence of Language, Symbolism, and Music - An Alternative Multidisciplinary Perspective, Journal of World Prehistory, 17(1), New York / Heidelberg, 1-71.

DŽAJA, K., 2003. - Katarina Džaja, Geomorfološke značajke Dugog otoka, Geoadria, 8/2, Zadar, 5-44

ĐURIČIĆ, LJ., 2006. - Ljiljana Đuričić, A contribution to research on Bioče Mousterian, Glasnik Srpskog arheološkog društva, 22, Beograd, 179-196.

KARAVANIĆ, I., 1999 - Ivor Karavanić, Gornji paleolitik Šandalje II u okviru Jadranske regije (neobjavljena disertacija), Zagreb.

KOMŠO, D., 2007 - Darko Komšo, Nakit na području Istre od paleolitika do neolitika. U: M. Blečić, M. Črešnar, B. Hänsel, A. Hellmuth, E. Kaiser, C. Metzner-Nebelsick (ur.) - Scripta praehistorica in honorem Biba Teržan, Situla, 44, Ljubljana, 31-40.

KOMŠO, D., PELlEGATI, P., 2007. - Darko Komšo, Paolo Pellegati, The late Epigravettian in Istria Late Palaeolithic colonization and lithic technology in the Northern Adriatic area, Late Paleolithic environments and cultural relations Adriatic (ed.: R. Whallon), BAR International Series 1716, Oxford, 27-39.

MALEZ, M., 1979. - Mirko Malez, Nalazišta paleolitskog i mezolitskog doba u Hrvatskoj, Praistorija Jugoslavenskih zemalia, I, Sarajevo, 227-276.

MARKS, A. et al., 1991. - Anthony E. Marks, Jeff Shokler, João Zilhao, Raw Material Usage in the Paleolithic: The Effects of Local Availability on Selection and Economy, Raw material economies among prehistoric hunter-gatherers (eds.: A. Montet-White, S. Holen), Publications in Anthropology 19, Lawrence, 127-139.

MITHEN, S., 2005. - Steven Mithen, A creative explosion? Theory of mind, language and the disembodied mind of the Upper Palaeolithic, Creativity in human evolution and prehistory (ed.: S. Mithen), Taylor \& Francis e-Library, 120-140.

MUSSI, M., 2002. - Margherita Mussi, Earliest Italy: An Overview of the Italian Paleolithic and Mesolithic, New York.

MUSSI, M. et al., 2008. - Margherita Mussi, Paul Bahn, Roberto Maggi, Parietal art discovered at Arene Candide Cave (Liguria, Italy), Antiquity, 83/316, York, 265-270.

RADIĆ, D. et al., 2008. - Dinko Radić, Boško Lugović, Ljerka Marjanac, Napuljski žuti tuf (NYT) iz pleistocenskih naslaga u Veloj spili na Korčuli: dragocjeni marker prijelaza iz paleolitika u mezolitik, Opuscula archaeologica, 31 (2007), Zagreb, 7-26.

RUNNELS, C., 1995. - Curtis Runnels, Review of Aegean Prehistory IV: The stone age of Greece from the Palaeolithic to the advent of the Neolithic, American journal of Archaeology, 99, Boston, 699-728.

SURIĆ, M. 2006. - Maša Surić, Promjene u okolišu tijekom mlađeg pleistocena i holocena - zapisi iz morem potopljenih siga istočnog Jadrana (disertacija), Zagreb.

VANHAEREN, M., D'ERRICO, F., 2005. - Marian Vanhaeren, Francesco d'Errico, Grave goods from the Saint-Germain-la-Rivierre burial: Evidence for social inequality in the Upper Palaeolithic, Journal of Anthropological Archaeology, 24, Elsevier, Amsterdam, 117-134. 


\section{Jewelry and Art of Vlakno Cave}

\section{SUMMARY}

The Vlakno cave is situated in the central part of the island of Dugi Otok between settlements Luka and Savar. The cave was suitable for dwelling of a smaller group throughout the year due to its look, size and orientation. The third campaign of the archaeological research was undertaken at the beginning of 2010 with the aim of determining complete startigraphy of the site so that the excavation was conducted within previously opened Trench B (fig. 1).

In the previous campaigns the level of tephra, Neapolitan Yellow Tuff was reached. Analyses indicate that this layer was formed 14500 years ago. In the new campaign additional $80 \mathrm{~cm}$ of deposits under tephra have been excavated, and the bottom of the cave was not reached until the end of the campaign. Under the tephra there are three main layers separated with two thin interlayers of ash and burnt soil which actually represent walking surfaces from the period when the cave was in use. Preliminary analyses of the material from all three layers indicate to the Epigravettian period corresponding with the general development of the Upper Palaeolithic on both sides of the Adriatic. Dates acquired for layers under tephra indicate age from 12.710 to 12.120 cal. years BC (14. 660 to 14. 060 cal. years BP).

At the beginning of the new excavation decrease of the remains of marine organisms was evident, and the remains of big terrestrial animals refer mostly to big ruminants. There are less flint tools, although they are still represented with a significant number of specimens. There are also bone tools, such as perforated teeth of a deer (Cervus elaphus), perforated shells and snails (Cyclope neritea, Columbella rustica and shells of the genus Glycimeris). Eight perforated deers' teeth were found, six different perforated shells and a bead made of a shell of the genus Entalina (Dentalium tetragonum) (fig. 2). Alongside these finds, we need to mention fragments of ten bone awls and punches.

Besides jewelry, meaning of the aesthetics gains even more importance regarding the find of two fragments of chert nodules in the same layer. One of them is decorated with a row of short, parallel and two horizontal incisions on the cortex (fig. 5). This was a segment of a larger depiction, continuing in three directions in relation to the extant segment. Unfortunately other fragments are missing which is why it is impossible to discuss the type of depiction. Nodule is broken, only its segment is preserved. It is triangular in cross-section, 3,6 cm long. Preliminary analyses indicate that it was exposed to heating before it was broken.

Another fragment of a nodule was found in the same layer, semicircular in cross-section. Incisions in the cortex are shallow, filling the entire surface as opposed to the previously mentioned fragment. This is a row of slanted parallel short incisions encircling the flake (fig. 6).

Meaning of these objects remains unknown until the time of possible discovery of some other fragment. There are no indications of functional characteristics of these incisions which is why it is reasonable to suppose that their purpose was of aesthetic nature to say the least. It is possible that depictions on the stone from Vlakno have far more complex meaning. Archaeologists assume that some of the art of the Upper Palaeolithic was used for information storage. Geometric forms might represent different marks or symbols, messages illegible to a modern man.

These are not the only decorated objects from Vlakno. On a bone awl is a row of horizontal, short incisions on the proximal part which were not created as a result of working or using bone (cutmarks) but they undoubtedly represent a decoration of the object. Similar incisions (four short incisions) were found on the distal part of the bone punch. These incisions can only have aesthetic meaning as well as on the previously mentioned example. However they may be a sign of ownership or affiliation to a group, or, since the incisions repeat, they may represent a system of numbers.

KeY Words: Dugi otok, Vlakno cave, Palaeolithic, Epigravettian, Chert nodule with incisions, jewelry

Prijevod / Translation: Marija Korona 